\title{
SUBTIDAL SOFT-BOTTOM MACROINVERTEBRATE COMMUNITIES OF THE CANARY ISLANDS. AN ECOLOGICAL APPROACH
}

\author{
Oscar Monterroso*, Rodrigo Riera and Jorge Núñez \\ Centro de Investigaciones Medioambientales del Atlántico (CIMA SL) \\ (Arzobispo Elías Yanes, 44, 38206 La Laguna, Tenerife, Canary Islands, Spain) \\ *Corresponding author: rodrigo@cimacanarias.com
}

\begin{abstract}
A B S T R A C T
The Canarian archipelago is characterized by a mosaic of soft-bottoms such as Cymodocea nodosa meadows, Caulerpa spp. meadows, mäerl bottoms, sabellid fields and bare sandy seabeds, including various macroinfaunal communities. Vegetated habitats (e.g. Cymodocea and Caulerpa) maintain more diverse communities than the non-vegetated seabeds. The results indicated that Caulerpa meadows and, to a lesser extent, Cymodocea nodosa and sabellid fields are the richest and most diverse ecosystems in the study area. Moreover, biodiversity differences among islands could be detected with maximum values on the eastern islands (Lanzarote and Gran Canaria) and lowest values on the western ones (La Palma).
\end{abstract}

\section{R ESUMO}

O arquipélago das Canárias é caracterizado por um mosaico de fundos inconsolidados contendo bancos de Cymodocea nodosa, Caulerpa spp., fundos calcários, bancos de sabelídeos e sedimento não biogênico, que abrigam diferentes comunidades da macrofauna. Ambientes vegetados (Cymodocea e Caulerpa) possuem comunidades mais diversificadas quando comparados aos ambientes de fundos não vegetados. Os resultados do presente estudo indicaram que os bancos de Caulerpa, primeiramente, e em seguida os bancos de Cymodocea nodosa e de sabelídeos, formam os sistemas mais ricos e diversificados da área. Além disso, puderam também ser detectadas diferenças de biodiversidade entre as ilhas do arquipélago, sendo os valores mais altos localizados nas ilhas ao leste (Lanzarote e Gran Canaria) e os menores nas ilhas à oeste (La Palma).

Descriptors: Soft-bottoms, meadows, Cymodocea, Caulerpa, macrofauna, Canary Islands, Atlantic Ocean.

Descritores: Fundos inconsolidados, baixios vegetados, Cymodocea, Caulerpa, macrofauna, Ilhas Canárias, Oceano Atlântico.

\section{INTRODUCTION}

In the Canary Islands, Cymodocea nodosa seagrass meadows (regionally legislated as an endangered species) usually grow on a high proportion of sandy substrates, where currents are moderate and a high sedimentation rate exists (REYES et al., 1995). For that reason it is located mainly along the eastern and southern coast of the islands, from 0 a $30 \mathrm{~m}$ depth, forming extensive subtital meadows (REYES et al., 1995; PAVÓN-SALAS et al., 2000). In some locations, $C$. nodosa meadows are mixed with the green alga Caulerpa (C. prolifera and C. racemosa) (PAVÓN-SALAS et al., 2000), this green alga usually substitutes in depth to Cymodocea in the coarse sandy substrates. We also observed in some areas that mixed communities (C. nodosa and Caulerpa spp.) are present together with the seagrass Halophila decipiens and even eel-garden (Heteroconger longissimus) assemblages (MONTERROSO et al., 2004).

Canarian macroinfauna seems to be characterized by local patches of high densites (> 100 ind $/ \mathrm{m}^{2}$ ) separated by a fairly variable inter-patch distance (HERRANDO-PÉREZ et al., 2001). Brito et al. (2005) studied the temporal variability of interstitial polychaetes on a Cymodocea nodosa meadow during a year. The dominant polychaete species were syllids (Streptosyllis bidentata, Exogone parahomoseta mediterranea and Streptosyllis campoyi) and paraonids (Aricidea assimilis and Cirrophorus perdidoensis). Unfortunately, scarce ecological data exist about the remaining studied seabeds (Caulerpa spp. meadows, Maërl, Sandy bottoms, Sabellids field and mixed, with Cymodocea and Caulerpa) and this information is provided by qualitative data from campaigns of seabed characterization. Thus, there are 
no available quantitative data for comparison from other Canarian areas.

In oceanographic terms, canarian macroinfaunal communities should be characterized by having low abundances because of the presence of oligotrophic atlantic waters, being richer in the proximity of the african coast by the presence of the saharian upwelling (BARTON et al., 1998).

The present study is the first attempt to characterize macroinfaunal communities from different islands of the Canarian archipelago (Lanzarote, Gran Canaria, Tenerife and La Palma), as well as, from different seabeds (C. nodosa meadows, Caulerpa spp. meadows, Maërl, Sandy bottoms, Sabellids field and mixed, with Cymodocea and Caulerpa). The studied areas are considered suitable for aquaculture cages and thus, the main aim of the present work is to evaluate macroinfaunal diversity from sandy seabeds of the Canary Islands in order to consider these communities for future environmental monitoring assessments.

\section{Material And Methods}

The present study was conducted at five coastal areas of Lanzarote, Gran Canaria (South-east and North-west), Tenerife and La Palma, where large sandy unvegetated habitats exist, crucial for the settlement of aquaculture cages. Six different seabeds were present in the studied areas: Cymodocea nodosa meadows, Caulerpa spp. meadows, Maërl, Sandy bottoms, Sabellids fields and mixed (C. nodosa and Caulerpa spp.). A total of 166 sites were sampled in the present study, 76 in sandy bottoms, 56 in Caulerpa meadows, 16 in $C$. nodosa meadows, 8 sabellids fields, 8 mixed (C. nodosa and Caulerpa) and 2 maërl bottoms (Fig. 1).

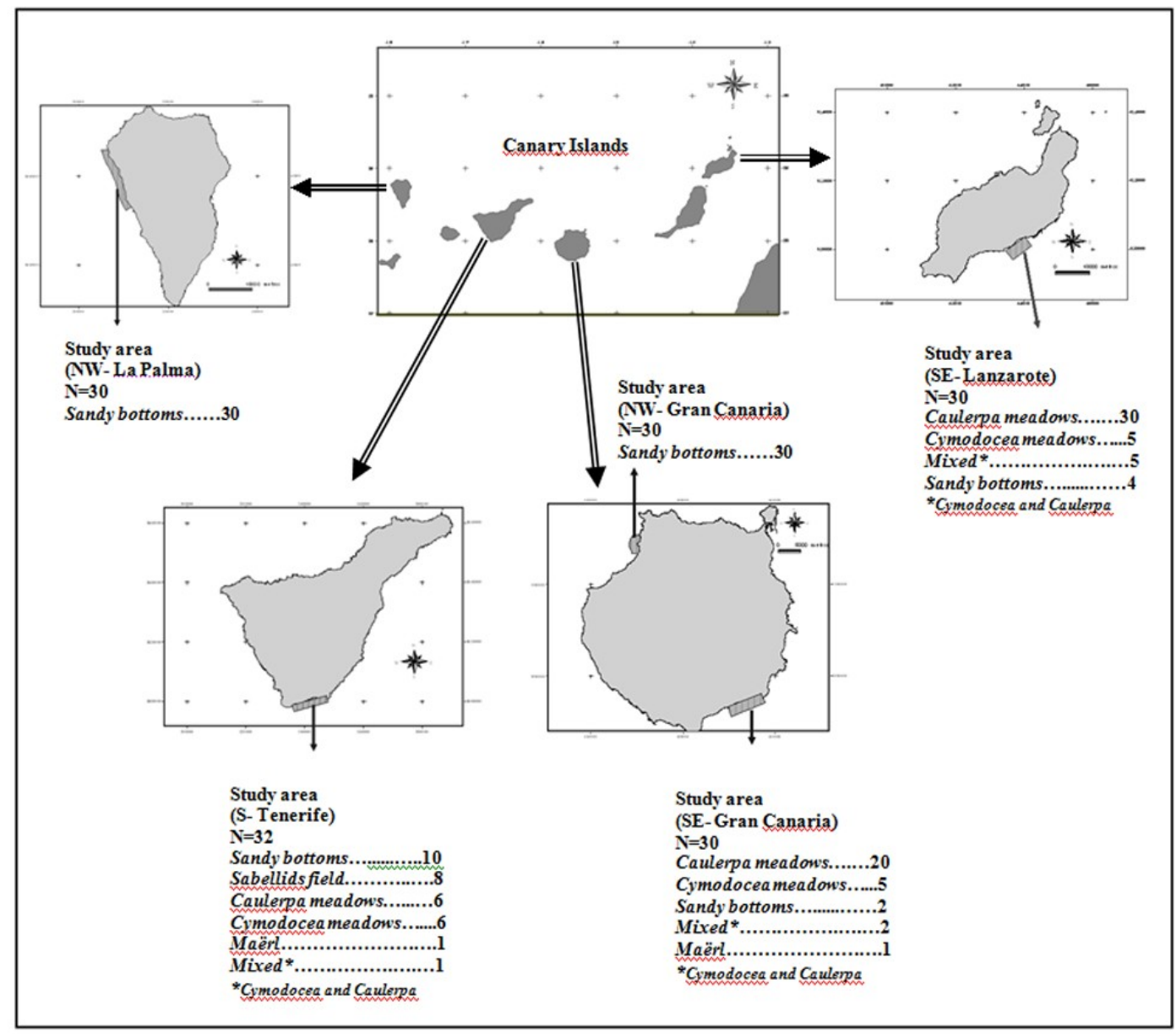

Fig. 1. Location of the study area and sampling sites, showing total number of sites per island $(\mathrm{N})$ and number of sites per habitat in each island. 
Sediment samples were taken during summer 2002 (July and August). Samples were collected by hand drilling into the sediment with a square metallic core $(20 \times 20 \mathrm{~cm}$, volume of the area unit $=800 \mathrm{~cm}^{3}$ ), to a depth of $20 \mathrm{~cm}$. Only infaunal specimens were identified, not epifaunal specimens of seagrass ( $C$. nodosa) or Caulerpa meadows, and abundances were represented by area unit. All sampling stations are subtidal (20-30 m). Three replicates were collected from each site for faunal analysis. No data concerning sedimentary properties of the seabed were sampled. Samples were preserved in $10 \%$ seawater buffered formaldehyde solution and sieved through a $1 \mathrm{~mm}$ mesh, commonly used in monitoring studies (less time-consuming). Specimens were sorted and counted under a binocular microscope and finally stored in $70 \%$ ethanol until microscopical analysis. Specimens were mounted in glycerine gelly on slides and examined by means of a LEICA DMLB microscope equipped with Nomarski interference contrast for their identification to species level, whenever possible.

Two different approaches were used to analyse the data:

1. Univariate analysis of macroinfaunal community descriptors (abundance, species richness, Margalef's richness and Shannon's diversity) using variance (Hierarchical ANOVA) to test the null hypothesis that the macroinfaunal community structure was similar across habitat within islands. The experimental design considered two factors: (a) habitat $(\mathrm{H})$, with six treatments (Cymododea meadows, Caulerpa meadows, Maërl, Sandy bottoms, Sabellids field and mixed, with Cymodocea and Caulerpa) and (b) site (S), with five treatments (SE-Lanzarote, NW-Gran Canaria, SE- Gran Canaria, S-Tenerife, NW-La Palma). Locations were nested in habitats.

2. Multivariate analysis of the similarities among communities based on species composition were established using n-MDS (non-metric multidimensional scaling). Data were square-root transformed and the Bray-Curtis similarity index was used. The ANOSIM routine (CLARKE, 1993) was used to analyze differences between islands and soft-bottoms communities, being identified the macrobenthic species responsible for the observed trends by means of SIMPER routine. Multivariate analyses were carried out using the PRIMER 5.2. package (Plymouth Routines In Multivariate Ecological Analysis) (CLARKE; WARWICK, 1994).

Differences between localities and communites in community descriptors (abundance, species richness, Margalef's richness and Shannon's diversity) were analyzed by means of one-way analysis of variance (ANOVA), after verifying normality using the Kolmogorov-Smirnov test and Levene test for homogeneity of variances. Data were square-root transformed to meet the assumptions of normality and homocedasticity required for parametrical analyses (UNDERWOOD, 1997).

\section{RESUlTS}

A total of 2,991 specimens were collected, belonging to 232 species and 15 taxonomic groups (Polychaetes, Oligochaetes, Turbellarians, Nematodes, Nemerteans, Amphipods, Cumaceans, Isopods, Misids, Decapods, Bivalves, Ophiuroids, Echinoids, Cephalochordates and Phoronids) (Table 1). Polychaetes were the most abundant group with 2.234 individuals, representing the $74.7 \%$ of the total abundance. The second most abundant group were amphipods with 433 individuals $(14.5 \%$ of the total abundance). These two groups accounted together the $89.2 \%$ of the overall abundance. Tanaids were the third group in terms of abundance and represented 3\% of the total abundance. The remaining taxonomic groups were scarce. In terms of species richness, polychaetes were the most diverse group with 131 taxa, followed by amphipods with 29 species.

The most abundant species was the sabellid Chone sp. with 305 individuals, followed by the onuphid Aponuphis bilineata and the paraonid Cirrophorus armatus, with 265 and 232 ind, respectively. In contrast, a total of 73 taxa were represented by one single specimen (Table 1 ).

Table 1. List of macrofaunal species collected at sampling stations [N IND total number of specimens; DOM Soyer's dominance (D dominant; d non-dominant); FREQ frequency, (A accessory; a accidental); Mean number of specimens (ind $\left.\mathrm{m}^{-2}\right) \pm \mathrm{SE}$ (Standard Error).

\section{COMMUNity Descriptors}

Islands

The highest abundances with a mean of 29.37 ind/area unit $\left(800 \mathrm{~cm}^{3}\right)$ were obtained in Lanzarote, followed by the south-east Gran Canaria with 24.8 ind/area unit. Tenerife and north-west Gran Canaria were characterized by having intermediate values, 17 and 16.5 ind/area unit, respectively. The lowest abundances were found in La Palma, with a mean of 10.5 ind/area unit (Fig. 2). However, no significant differences were found among islands (One-way ANOVA, F = 0.75, p = 0.43). 
As occurred to the abundance, the highest values of Margalef's richness were obtained in Lanzarote, with a mean of 11.30 , followed by southeast Gran Canaria with 10.63. Tenerife and north-west Gran Canaria were characterized by having intermediate values, with 7.16 and 6.13, respectively. In La Palma were obtained the lowest richness with a mean of 4.16. No significant differences were recorded among islands (One-way ANOVA, $\mathrm{F}=0.88$, $\mathrm{p}=0.76)$.

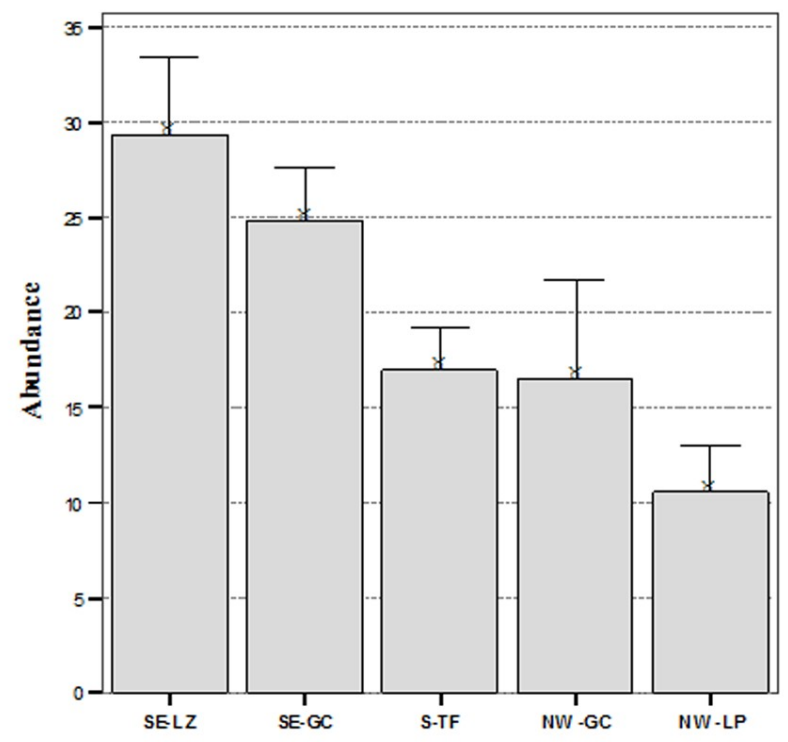

Fig. 2. Mean abundances (per area unit: $800 \mathrm{~cm}^{3}$ ) of total sampling stations ( $\pm 1 \mathrm{SE}$ ) per site (SE-LZ, southeast Lanzarote; SE-GC, southeast Gran Canaria; S-TF, south Tenerife, NW-GC, northwest Gran Canaria; NW-LP, northwest La Palma).

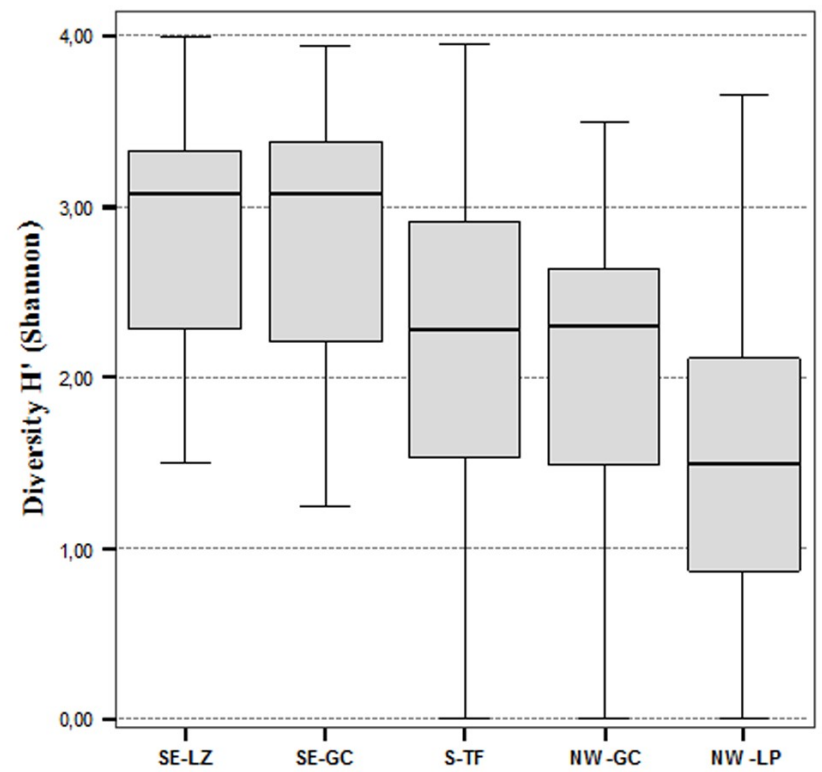

Fig. 3. Shannon's Diversity of total sampling stations $\left(\mathrm{H}^{\prime}\right)$ per site (SE-LZ, SouthEast Lanzarote; SE-GC, South-East Gran Canaria; S-TF, South Tenerife; NW-GC, 
North-West Gran Canaria; NW-LP, North-West La Palma). Box-plot showing median (black line) and upper and lower quartiles of the data.

In terms of Shannon's diversity $\left(\mathrm{H}^{\prime}\right.$, log basis $\ln$ ) highly significant differences were found among islands (One-way ANOVA $\mathrm{F}=10.181$; $\mathrm{p}<$ 0.0001). The highest diversity was found in Lanzarote with 2.75 , followed by Gran Canaria and Tenerife with 2.42 and 2.19, respectively. The lowest diversity was obtained in La Palma with 1.46 (Fig. 3).

Pielou's evennes showed high values in all studied islands, ranging from 0.72 in La Palma to 0.86 in Gran Canaria. No significant differences were found among islands (One-way ANOVA, $\mathrm{F}=0.92 ; \mathrm{p}=0$. 70).

\section{Habitats}

Mixed seabeds (Cymodocea and Caulerpa) harbour the highest abundances (28.12 ind/area unit), followed by Caulerpa meadows and Sabellids fields, with 25.97 and 25.17 ind/area unit, respectively. To the contrary, the lowest abundances were found in sandy bare seabeds (14.09 ind/area unit). No significant differences were found among islands (One-way ANOVA, $\mathrm{H}=0.88$; $\mathrm{p}=0.55$ ).

Margalef's richness varied among the studied habitats, ranging from 1.79 in sandy bare seabeds to 3.46 in mixed communities (Cymodocea and Caulerpa). No significant differences were found among habitats (One-way ANOVA, F = 0.95; $\mathrm{p}=$ 0.85).

The mixed community CaulerpaCymodocea obtained the highest diversity $\left(\mathrm{H}^{\prime}=3.17\right)$, followed by Caulerpa meadows community $\left(\mathrm{H}^{\prime}=\right.$
2.76). Intermediate diversity values were recorded in Maërl (2.26), Cymodocea nodosa seagrass meadows (2.20) and Sabellids field (2.30). The sandy bare seabed community harboured the lowest diversity $(\mathrm{H}$ $'=1.86$ ), however, no significant differences were found among habitats (One-way ANOVA, $\mathrm{F}=0.98$; $\mathrm{p}$ $=0.73$ ). All habitats showed high evenness values ranged from 0.79 in sandy bottoms to 0.90 in mixed community (Caulerpa-Cymodocea), indicating the absence of species that clearly dominate the macrofaunal community. No significant differences were found among the studied habitats (One-way ANOVA, $\mathrm{F}=0.79 ; \mathrm{P}=0.52$ ) (Table 2).

\section{Macrofaunal Community Structure}

A non-parametric multidimensional scaling (n-MDS) revealed differences among the five different locations (La Palma, North-West Gran Canaria, SouthEast Gran Canaria, Lanzarote and Tenerife) (Fig. 4). ANOSIM results obtained significant differences $(\mathrm{R}=$ 0.212, $\mathrm{p}=0.001$ ) among locations, being clearly separated macrofaunal communities of La Palma (NW-LP) from the remaining ones.

A non parametric multidimensional scaling (MDS) revealed slight differences, as shown as not significant in ANOSIM results $(\mathrm{R}=0.055, \mathrm{p}=0.08)$ among the six different soft-bottom communities, although Caulerpa meadows communities were clearly separated from the remaining seabeds (Fig. 5).

Table 2. Minimum, maximum and mean values of community descriptors (Shannon's diversity, Pielou's evenness and Margalef 's richness) of the six different habitats. SD: Standard Deviation; n: number of sampling locations.

\begin{tabular}{clrrrr}
\hline \hline & & & & & \\
& & Min. & Max. & Mean \\
& & 0 & 3.95 & 2.76 & 1.02 \\
Caulerpa meadows & Diversity $\left(H^{\prime}\right)$ & 0 & 1.00 & 0.83 & 0.24 \\
& Evenness $\left(J^{\prime}\right)$ & 0 & 5.67 & 3.03 & 1.39 \\
& Richness $(d)$ & 0 & 3.37 & 2.20 & 1.03 \\
Cymodocea meadows & Diversity $\left(H^{\prime}\right)$ & 0 & 1.00 & 0.81 & 0.24 \\
& Evenness $\left(J^{\prime}\right)$ & 0 & 5.07 & 2.36 & 1.39 \\
$(\mathrm{n}=16)$ & Richness $(d)$ & 1.74 & 2.78 & 2.26 & 0.74 \\
Maërl & Diversity $\left(H^{\prime}\right)$ & 0.75 & 0.88 & 0.82 & 0.09 \\
& Evenness $\left(J^{\prime}\right)$ & 1.36 & 2.82 & 2.09 & 1.03 \\
$(\mathrm{n}=2)$ & Richness $(d)$ & 2.24 & 3.99 & 3.17 & 0.58 \\
Mixed & Diversity $\left(H^{\prime}\right)$ & 0.81 & 0.98 & 0.90 & 0.06 \\
& Evenness $\left(J^{\prime}\right)$ & 2.06 & 5.3 & 3.47 & 1.11 \\
$(\mathrm{n}=8)$ & Richness $(d)$ & 1.44 & 3.06 & 2.30 & 0.57 \\
Sabellid fields & Diversity $\left(H^{\prime}\right)$ & 0.61 & 0.96 & 0.81 & 0.13 \\
& Evenness $\left(J^{\prime}\right)$ & 1.41 & 3.32 & 2.08 & 0.66 \\
(n=8) & Richness $(d)$ & 0 & 3.88 & 2.86 & 1.00 \\
Sandy bottons & Diversity $\left(H^{\prime}\right)$ & 0 & 1 & 0.79 & 0.30 \\
& Evenness $\left(J^{\prime}\right)$ & 0 & 5.02 & 1.86 & 1.16 \\
\hline & Richness $(d)$ & & &
\end{tabular}




$$
(n=76)
$$

Macroinfaunal species that accounts for the similarities between all studied samples were the polychaetes Aponuphis bilineata and Chone sp., although several species were typical of one single seabed, such as, Glycera oxycephala in Caulerpa meadows, Galatowenia oculata in Cymodocea meadows, Bispira viola in sabellids field and the amphipod Urothoe marina in sandy bare seabeds (Table 3).

\section{DisCUSSION}

Six different soft-bottom habitats were sampled (Caulerpa meadows, Cymodocea nodosa meadows, Mixed community, Sabellids field, Mäerl and Sandy bare seabeds) and the highest macroinfaunal diversity was recorded in mixed community (Caulerpa and Cymodocea) and Caulerpa meadows, intermediate values were recorded in $C$. nodosa meadows, Maërl and Sabellids field. However, these results should be taken with caution, since Caulerpa meadows (56 stations) and sandy bare seabeds (76 stations) were sampled extensively compared with the remaining habitats. In contrast, maërl, mixed community (Caulerpa and Cymodocea) and sabellids field were represented by a small number of stations. The main consequence of this unbalanced number of samples is the lack of significant differences among studied sandy seabeds, specially between vegetated (C. nodosa, Caulerpa and mixed communities) and unvegetated substrates.

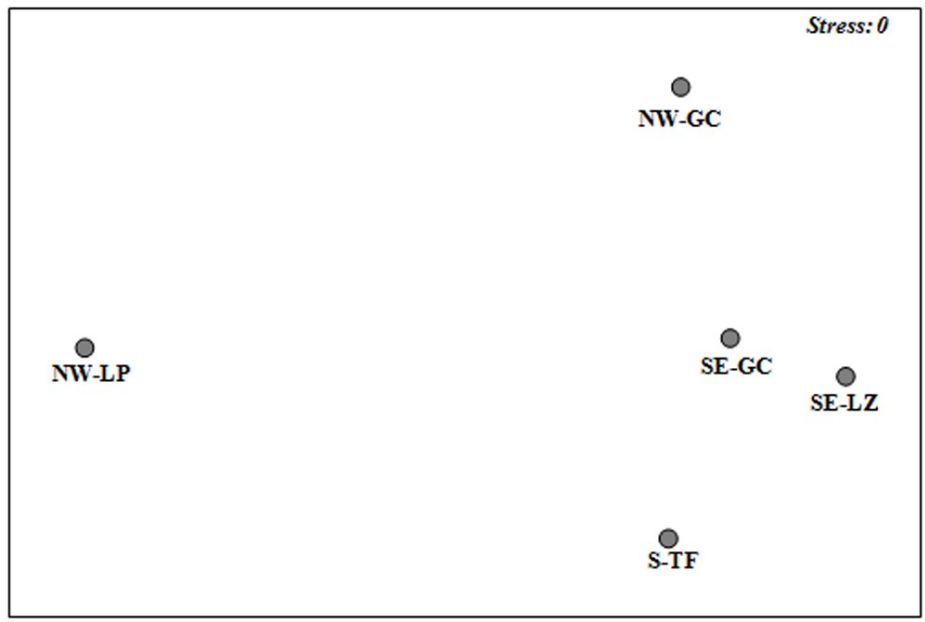

Fig. 4. Non multidimensional scaling (n-MDS) showing the five different sites (SE-LZ, South-East Lanzarote; SE-GC, South-East Gran Canaria; S-TF, South Tenerife; NW-GC, North-West Gran Canaria; NW-LP, North-West La Palma). Stress value $=0.15$. 


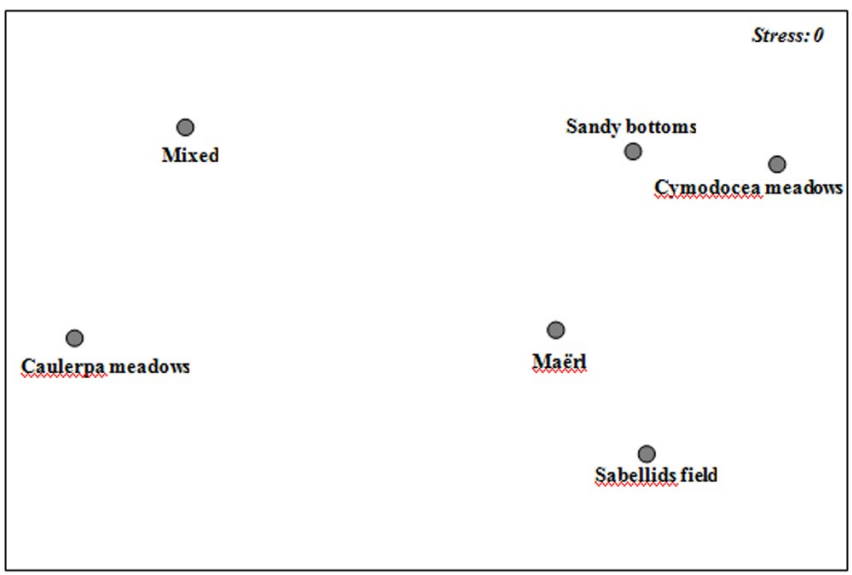

Fig. 5. Non multidimensional scaling (n-MDS) showing the six different habitats. Stress value $=0.11$.

Table 3. Mean abundances of the species with the greatest similarity of all the groups obtained by the multivariate analyses according to the SIMPER routine. Mäerl community not represented because of scarcity of data. Contribution cutoff $(5 \%)$.

\begin{tabular}{llrrrrr}
\hline \hline & Species & $\begin{array}{c}\text { Av. } \\
\text { Abund }\end{array}$ & $\begin{array}{c}\text { Av. } \\
\text { Sim }\end{array}$ & Sim/SD & $\begin{array}{c}\text { Contrib } \\
\text { \% }\end{array}$ & $\begin{array}{c}\text { Cum. } \\
\text { \% }\end{array}$ \\
\hline \multirow{5}{*}{ Caulerpa meadows } & Aponuphis bilineata & 3.12 & 3.8 & 0.76 & 27.9 & 27.9 \\
& Chone sp & 4.49 & 3.71 & 0.54 & 27.21 & 55.11 \\
& Chone collaris & 1.39 & 0.93 & 0.3 & 6.82 & 61.94 \\
& Cirrophorus armatus & 1.02 & 0.77 & 0.34 & 5.65 & 67.58 \\
& Aponuphis bilineata & 3.62 & 6.16 & 0.65 & 42.72 & 42.72 \\
Cymodocea meadows & Ampelisca brevicornis & 2.12 & 1.99 & 0.43 & 13.79 & 56.52 \\
& Chone sp & 0.75 & 1.39 & 0.4 & 9.66 & 66.17 \\
& Cirrophorus armatus & 2.94 & 1.31 & 0.41 & 9.05 & 75.22 \\
& Galathowenia oculata & 0.75 & 1.07 & 0.36 & 7.4 & 82.62 \\
& Chonesp & 1.88 & 1.83 & 0.49 & 13.89 & 13.89 \\
Mixed & Aponuphis bilineata & 1.88 & 1.79 & 0.49 & 13.57 & 27.46 \\
& Scoloplos (Leodamas) sp & 1.38 & 1.51 & 0.66 & 11.45 & 38.91 \\
& Cirrophorus perdidoensis & 3 & 1.5 & 0.34 & 11.37 & 50.27 \\
Sabellid fields & Cirrophorus armatus & 0.88 & 1.36 & 0.45 & 10.3 & 60.58 \\
& Bispira viola & 7.38 & 10.69 & 0.79 & 35.93 & 35.93 \\
& Cirrophorus armatus & 3.38 & 8.54 & 1.12 & 28.7 & 64.63 \\
& Chonesp & 5.88 & 6.76 & 0.92 & 22.73 & 87.36 \\
Sandy bottom & Cirrophorus armatus & 1.45 & 1.11 & 0.28 & 23.38 & 23.38 \\
& Aponuphis bilineata & 0.71 & 0.7 & 0.23 & 14.78 & 38.16 \\
& Galathowenia oculata & 0.56 & 0.32 & 0.15 & 6.76 & 44.92 \\
& Urothoe marina & 0.43 & 0.32 & 0.15 & 6.7 & 51.62 \\
& Glycera oxycephala & 0.25 & 0.29 & 0.15 & 6.06 & 57.67 \\
& Prionospio steenstrupi & 0.27 & 0.27 & 0.13 & 5.56 & 63.23 \\
\hline
\end{tabular}

However, significant differences were found among islands, with a trend from the eastern island (Lanzarote) to the western island (La Palma). This trend agrees well with the influence of the saharian upwelling (West coast of Africa), that directly affects the eastern islands of the archipelago (Lanzarote and Fuerteventura, and to a lesser extent, Gran Canaria), with rich and cold waters (BARTON et al., 1998). In contrast, the western islands (La Palma, La Gomera and El Hierro) are characterized by oligotrophic waters, without connection with richer water masses.

In this study, polychaetes characterized the macrofaunal community structure of the sampling stations ( $>74 \%$ of the overall abundance). This taxonomic group has been considered a reliable descriptor of soft-bottom communities, due to the great speciecs diversification (SOMASCHINI et al., 1994). Brito et al. (2005) demonstrated the presence of a diverse polychaetofauna in seagrass meadows ( $C$. nodosa) of the Canary Islands, being usually much higher the abundance, species richness and diversity in the meadows that in the adjacent sandy bare sediments. However, other authors observed that most species inhabiting rhizomes of Posidonia oceanica (seagrass not present in the Canarian archipelago) are also typical of the soft bottoms that occur in the nearby sand (LANERA; GAMBI, 1993). Furthermore, important variations of the community structure has 
been observed in seagrass meadows of the Canary Islands compared to adjacent areas (Mediterranean Sea) (BRITO et al., 2005) although the families Syllidae, Spionidae, Paraonidae and Capitellidae are considered the most abundant taxa among the polychaete fauna in both geographical regions (GIANGRANDE; GAMBI, 1986).

The habitat structure of Caulerpa prolifera beds, with developed and declined cover on a small spatio-temporal scale, leads to a high degree of heterogeneity which must produce a spatio-temporal pattern of macrofaunal species distribution (SÁNCHEZ-MOYANO et al., 2007). The C. prolifera formations, even though they do not constitute such a rich and structured system as the seagrass meadows, allow the settlement of important macrofaunal communities. This phenomenon is more accused in impoverished environments with scarce water exchange and with considerable input of organic matter (e.g. harbours) (SÁNCHEZ-MOYANO et al., 2001). Even in some cases, Caulerpa beds show richer communities than more structured seagrass meadows. In other studies, 49 crustacean species were recorded in other Caulerpa beds at the southern Atlantic coast of Spain (LÓPEZ DE LA ROSA et al., 2002) or 45 crustacean taxa along a seasonal study basis in Algeciras Bay (Southern Spain) (SÁNCHEZMOYANO et al., 2007). In the present study, a total of 36 crustacean species were registered in Caulerpa meadows, showing a more diverse macrofaunal communities than other studies carried out in other Caulerpa species, such as, C. racemosa in the Eastern Mediterranean Sea (ARGYROU et al., 1999) and C. taxifolia at Mediterranean coast of France (BELLANSANTINI et al., 1996).

This contribution constitutes one of the first attempts on the macrofaunal community structure of the canarian soft-bottoms and thus, little is known about the ecology of the associated communities. Moreover, this paper groups the most important marine sandy seabeds of the Canary Islands (Cymodocea nodosa meadows, Caulerpa meadows, mixed communities, Mäerl bottoms, sandy bare sediments and sabellids fields).

In short, several general conclusions about community structure can be made. Species richness and diversity is higher in vegetated seabeds, especially in mixed community (Cymodocea-Caulerpa) and Caulerpa meadows, although intermediate values were found in Cymodocea nodosa meadows and sabellids field. Sandy bare sediments (non-vegetated) are characterized by low species richness and diversity, so habitat complexity determines infaunal community structure and increases the number of microhabitats that could be inhabited by different species. Moreover, a spatial trend can be discerned in the canarian archipelago, with highest abundances in eastern islands (Lanzarote and Gran Canaria) and lowest densities in western islands (La Palma).

\section{ACKNOWLEDGEMENTS}

We are grateful to Dr. José Manuel GuerraGarcía (University of Sevilla, Spain) for insightful comments on an earlier draft of the present manuscript. Thanks are also to J. Falcón, A. Moreira and J.C. Hernández for field assistance during sampling campaigns.

\section{REFERENCES}

ARGYROU M.; DEMETROPOULOS, A.; HADJICHRISTOPHOROU, M. Expansion of the macroalga Caulerpa raemosa and changes in soft-bottom macrofaunal communities in Moni Bay, Cyprus. Oceanologica Acta, v. 22, n. 5, p. 517-528, 1999.

BARTON E. D.; ARÍSTEGUI, J.; TETT, P.; CANTÓN, M.; GARCÍA-BRAUN， J.; HERNÁNDEZ-LEÓN， S.; NYKJAER. L.; ALMEIDA, C.;ALMUNIA, J.; BALLESTEROS, S.; BASTERRETXEA, G.; ESCÁNEZ, J.; GARCÍA-WEILL，L.; HERNÁNDEZGUERRA, A.; LÓPEZ-LAATZEN, F.; MOLINA, R.; MONTERO, M. F.; NAVARRO-PÉREZ, E.; RODRÍGUEZ, J. M.; VAN LENNING, K.;VÉLEZ, ; WILD, K. The transition zone of the Canary Current upwelling region. Progr. Oceanogr., v. 41, p. 455-504, 1998.

BELLAN-SANTINI, D.; ARNAUD, P. M.; BELLAN, G.; VERLAQUE, $M$. The influence of the introduced tropical alga Caulerpa taxifolia, on the biodiversity of the Mediterranean marine biota. J. mar. biol. Ass. U. K., v. 76, p. 235-237, 1996.

BRITO, M. C.; NÚÑEZ, J.; MARTÍN, D. Polychaetes associated to a Cymodocea nodosa meadow in the Canary Islands: community structure, temporal variability and vertical distribution compared to other Mediterranean seagrass meadows. Mar. Biol., v.146, p. 467-481, 2005.

CLARKE, K. R. Non-parametric multivariate analyses of changes in community structure. Aust. J. Ecol., v. 18, p. 117-143, 1993.

CLARKE, K. R.; WARWICK, R. M. Changes in marine communities: an approach to statistical analysis and interpretation. Plymouth: Plymouth Marine Laboratory, U.K., 1994. $144 \mathrm{p}$.

GIANGRANDE, C.; GAMBI, M. C. Polychètes d'une pelouse de Cymodocea nodosa (Ucria) Aschers du Golfe du Salerno (Mer Tyrrhénienne). Vie Milieu, v. 36, p.185-190, 1986.

HERRANDO-PÉREZ, S.; SAN MARTÍN, G.; NÚÑEZ, J. Polychaete patterns from an oceanic island in the Eastern Central Atlantic: La Gomera (Canary archipelago). Cah. Biol. mar., v. 42, n. 3, p. 275-287, 2001.

LANERA, P.; GAMBI, M. C. Polychaete distribution in some Cymodocea nodosa meadows around the Island of Ischia (Gulf of Naples Italy). Oebalia, v. 19, p. 89-103, 1993. 
LÓPEZ DE LA ROSA, I.; GARCÍA-RASO, J. E; RODRÍGUEZ, A. Evolution of a decapod community (Crustacea) of shallow soft bottoms with seaweeds from southern Europe. J. mar. biol. Ass. U. K., v. 82, p. 8595, 2002.

MONTERROSO, O.; NÚÑEZ, J.; RIERA, R. Macrofauna de fondos blandos en las concesiones de acuicultura de la bahía de Igueste de San Andrés, Tenerife. Revta Acad. Canaria Cienc., v. 15, n.3/4, p. 77-86, 2004.

PAVÓN-SALAS, N.; HERRERA, R.; HERNÁNDEZGUERRA, A.; HAROUN R.J. Distributional pattern of seagrasses in the Canary Islands (Central-East Atlantic Ocean). J. coast. Res., v. 16, p. 329-335, 2000.

REYES, J.; SANSÓN, M.; CARRILLO, A. Leaf phenology, growth and production of the seagrass Cymodocea nodosa at El Médano (South of Tenerife, Canary Islands). Botanica mar., v. 38, p. 457-465, 1995.

SÁNCHEZ-MOYANO, E. M.; GARCÍA-ADIEGO, F. J.; ESTACIO, F.; GARCÍA-GÓMEZ, J. C. Influence of the density of Caulerpa prolifera (Chlorophyta) on the composition o the macrofauna in a meadow in Algeciras bay (Southern Spain). Ciencias mar., v. 27, n. 1, p. 4771, 2001.

SÁNCHEZ-MOYANO, E.; GARCÍA-ASENCIO, I.; GARCÍA-GÓMEZ, J. C. Effects of temporal variation of the seaweed Caulerpa prolifera cover on the associated crustacean community. Mar. Ecol.,v. 28, p. 324-337. 2007.

SOMASCHINI, A.; GRAVINA, M. F; ARDIZZONE, G. D. Polychete depth distribution in a Posidonia oceanica bed (rhizome and mattestrata) and neighbouring soft and hard bottoms. Mar. Ecol., v. 15, p. 133-151, 1994.

UNDERWOOD, A. Experiments in ecology: their logical design and interpretation using analysis of variance. Cambridge: Cambridge University Press, 1997.

(Manuscript received 06 December 2011; revised 25 January 2012; accepted 2 March 2012) 